\title{
An update on reservoir operating rules following changes on the effective capacity due to land erosion
}

\author{
Azmeri Azmeri ${ }^{*}$, Devi Sundary ${ }^{1}$, Cut Mutiawati ${ }^{1}$, Hafnidar A. Rani ${ }^{2}$ \\ ${ }^{1}$ Civil Engineering Department, Universitas Syiah Kuala, Abdur-Rauf street No. 7 Darussalam Banda Aceh, 23123, Indonesia \\ ${ }^{2}$ Civil Engineering Department, Universitas Muhammadiyah Aceh, Muhammadiyah street No. 91 Batoh Banda Aceh 23245, \\ Indonesia
}

\begin{abstract}
Reservoirs play a role in decreasing the temporal variability of river flow by regulating the reservoir water release for several downstream water needs. The Keuliling Reservoir was built to meet the needs of irrigation water. However, the dry season in Aceh Besar Regency significantly impacts irrigation areas because water from the Keuliling Reservoir cannot meet the demands. During the dry season, which is also the beginning of the second rice planting season (for gadu rice variety), the water source of the Keuliling Reservoir significantly decreases. The rate of land erosion leads to sedimentation, which may cause a reduction in the effective reservoir capacity. A decline in reservoir function due to sedimentation can affect the reservoir's performance. The reservoir operating rules need to be adjusted due to a decline in capacity caused by sedimentation. This study aims to develop updated reservoir operating rules that can be used as an operational guideline for the Keuliling Reservoir. The study used a non-linear program to optimize the reservoir operation, which required objective functions and constraints. Optimization will result in reservoir operations that can supply water according to the target rice field area in normal and wet years. The irrigation area is 578 hectares for Group I (Keuliling Upstream Irrigation Area) and 1053 ha for Group I (Keuliling Downstream Irrigation Area). However, in the dry year of Group I (DI Keuliling Hulu), with an irrigation area of 578 hectares, the rice planting pattern (one rice planting season) begins with the planting season in October I. In addition, in Group II (DI Keuliling Hilir), with an irrigation area of $781 \mathrm{ha}$, the rice planting pattern (one rice planting season) starts the planting season in October II. The reduced inflows during dry years have decreased the target irrigation area by $113 \mathrm{ha}$. This Keuliling Reservoir operating manual can determine the reservoir water release to balance it with needs and storage targets.
\end{abstract}

\section{Introduction}

Water is an essential resource for humanity but at times becomes scarce and requires a struggle to obtain, especially in dry areas [1]. Water is primarily used for consumption; thus, its availability needs to be wellplanned to prevent conflicts among water users.

Reservoirs play a critical role in ensuring the availability of water and meeting various water demands. Reservoirs can reduce the temporal variability of flows by adjusting the release. However, water release controlled from reservoirs has a downstream detrimental effect if it neglects the ecological river flows [2].

Decision-makers often face difficulties in selecting the appropriate system for reservoir water management. The decisions taken can be controversial because of different water users of the implementation of the alternatives provided [3]. Therefore, optimization of water resource management is carried out to evaluate various modifications of reservoir operations. An optimum reservoir operating system has a vital role in meeting downstream water demands [4].
Improvements to the reservoir operating system are also required if variations in hydrological conditions, such as climate change and reservoir storage capacity alterations due to sedimentation, occur [5].

The dry season in Aceh Besar Regency significantly impacts irrigation areas because water from the Keuliling Reservoir cannot meet the demands. During the dry season, which is also the beginning of the second rice planting season (for gadu rice variety), the water source of the Keuliling Reservoir significantly decreases. The rate of land erosion leads to sedimentation, which may cause a reduction in the effective reservoir capacity. A decline in reservoir function due to sedimentation can affect the reservoir's performance.

Previous studies suggest that reservoir operations need to be updated due to sedimentation problems [6, 7]. The adjustments are required to control sedimentations and operations and, thus, produce a good performance. The reservoir operating rules need to be adjusted due to a decline in capacity caused by sedimentation. This study aims to develop updated reservoir operating rules that can be used as an operational guideline for the Keuliling Reservoir.

${ }^{*}$ Corresponding author: azmeri@unsyiah.ac.id 


\section{Reservoir operation formula}

The development of the reservoir operation model is done by identifying reservoir inflow and outflow. The reservoir inflow is a long-term time-series data, while the reservoir outflow is the reservoir evaporation in the forms of irrigation needs, ecological river flows, spillway discharge [8].

The reservoir operation modeling formulation is the conservation of water balance for time intervals, as the following formula:

$$
V_{t}-V_{u}=\Delta V=I_{t}-R_{t}-E_{t}-L_{l}
$$

where:

$V_{t-1} \quad:$ The water volume stored in the $\mathrm{t}_{-1}$ time $\left(\mathrm{m}^{3}\right)$;

$V_{t} \quad:$ The water volume stored in the $\mathrm{t}$ time $\left(\mathrm{m}^{3}\right)$;

$I_{t} \quad$ : The inflow discharge in $\mathrm{t}$ time $\left(\mathrm{m}^{3} / \mathrm{s}\right.$ in $\mathrm{t}$ time $\left(\mathrm{m}^{3} / \mathrm{s}\right)$;

Rt : The release of water from the reservoir $\left(\mathrm{m}^{3} / \mathrm{s}\right)$;

$E_{t} \quad:$ The evaporation in $\mathrm{t}$ time $\left(\mathrm{m}^{3}\right)$; and

$L_{t} \quad$ : The other water loss in $\mathrm{t}$ time $\left(\mathrm{m}^{3}\right)$.

Bathymetri process at Waduk Keuliling is carried out at Waduk Keuliling Area. The depth measurement of the Keuliling reservoir was performed using the ultrasonic wave reflection method which is perpendicularly emitted to the bottom of the water surface using the transducer (an echo sounder tool) and then the wave will be reflected back to the transducer [9].

\section{Modeling of Keuliling reservoir operation optimization}

The following are the parameters used in the stages of modeling the operation of the Keuliling Reservoir:

\section{Flow Discharge}

The river discharge data were from five channels leading to the Keuliling Reservoir. The discharge data were from the rain data undergoing rainfall-runoff analysis from 1995 to 2015 . Then, semi-monthly discharges were $20 \%, 50 \%$, and $80 \%$ for the wet, normal, and dry years.

2. Irrigation water need and the ecological river flows

a. Data showed that the area of the irrigation served by the Keuliling Reservoir was 2,131 Ha (Balai Wilayah Sungai Sumatera I 2010).

b. The minimum river flow that must be available at all times as ecological river flows to maintain the life of river biota is $5 \%$ of the Alue Keuliling River discharge.

3. Parameters of Keuliling Reservoir Operation Optimization

The optimization method requires an objective function, a constraint function, and a decision variable to obtain an optimal reservoir operation pattern. Each function is explained in the following sections:

\section{a. Objective function}

The optimization target is the objective function of the Keuliling Reservoir operation system. This objective function is to maximize the release of irrigation water to supply water for the agricultural area where the rainfall does not meet the water needs for crops [8].

\section{b. Constraint function}

The constraint function applies to storage reservoirs. At each stage of the operation, the reservoir storage volume is limited by the maximum and minimum operation volume.

$V_{\min } \leq V_{t} \leq V_{\max } \rightarrow V_{t}=V_{I} s / d V_{24}$

In addition, there is an obstacle in the release of water from the reservoir $(R t)$ that must be sufficient for the capacity of river, maintenance flow, and irrigation water demand. Vmin and Vmax are reservoir life storage limits.

$R_{I} s / d R_{24} \geq M F$ (Maintenance Flow)

$R_{1} s / d R_{24} \geq C R$ (Capacity of River)

$R_{1} s / d R_{24} \geq$ Demands

The reservoir water level in the 25th semi-month or at the beginning of semi-month for the operation of the following year must be greater than or equal to the water level at the beginning of the operating year.

$T M A_{\text {semi-month } 25} \geq T M A_{t=1}$

\section{c. Decision variable}

The amount of reservoir water release limited by constrained conditions is a decision variable in the operation of the reservoir for semi-monthly needs in the operating period of the wet year $(20 \%)$, normal year $(50 \%)$, and dry year $(80 \%)$.

The study used a non-linear program to optimize the reservoir operation, which required objective functions and constraints. The release of water from the reservoir intended to satisfy irrigation water demands is the decision variable [2]. The study observed a connection between land erosion, changes in effective capacity, and adjustments in reservoir operating rules. The rules are helpful as an operational guideline during dry, normal, and wet years.

\section{Results and discussion}

After conducting bathymetry measurement of the Keuliling Reservoir inundation, a re-analysis was carried out on the changes in the reservoir capacity. If compared to the results of the 2015 measurements, a decrease in reservoir capacity due to sedimentation was observed. The situation required adjustments to the reservoir operating rules. An optimal operating condition was obtained by analyzing the optimal operating rules; thereby, maintaining the reservoir's function to control flood and supply irrigation water. Optimization will result in reservoir operations that can supply water according to the target rice field area in normal and wet years. The irrigation area is 578 hectares for Group I (Keuliling Upstream Irrigation Area) and 1053 ha for Group I (Keuliling Downstream Irrigation Area). However, in the dry year of Group I (DI Keuliling Hulu), with an irrigation area of 578 ha, the rice planting pattern (one rice planting season) begins with the planting season in October I. In addition, in Group II (DI Keuliling Hilir), with an irrigation area of 781 ha, the rice planting pattern (one 
rice planting season) starts the planting season in October II. The reduced inflows during dry years have decreased the target irrigation area by 113 ha. In dry years, the initial water level is set at $+45.8 \mathrm{~m}$ (elevation of the total reservoir capacity) to optimize the total reservoir release. The variable used is a semi-monthly reservoir release for total demand, including for irrigation and maintenance. The constraints in dry years include a water level above $+40 \mathrm{~m}$ at the end of the operating year and a semi-monthly reservoir release greater than the total demand. Another constraint is a semi-monthly volume larger than the minimum volume and less than the maximum reservoir volume. The irrigation area in year 2013 and the target of area after study sediment that can be irrigated for each group are given in Table 1.

Table 1. Irrigation area year 2013 and exiting area

\begin{tabular}{|c|c|c|c|c|c|c|}
\hline \multirow{2}{*}{ Periode } & \multicolumn{3}{|c|}{ Irrigation Area year 2013 (Ha) } & \multicolumn{3}{|c|}{ Existing Irrigation Area (Ha) } \\
\cline { 2 - 7 } & Group I & $\begin{array}{l}\text { Group } \\
\text { II }\end{array}$ & $\begin{array}{l}\text { Group } \\
\text { III }\end{array}$ & Group I & $\begin{array}{l}\text { Group } \\
\text { II }\end{array}$ & $\begin{array}{l}\text { Group } \\
\text { III }\end{array}$ \\
\hline Wet & $\mathbf{5 7 8}$ & $\mathbf{1 0 5 3}$ & $\mathbf{5 0 0}$ & $\mathbf{5 7 8}$ & $\mathbf{1 0 5 3}$ & $\begin{array}{c}\mathbf{8 0 9} \\
(+309)\end{array}$ \\
\hline Normal & $\mathbf{5 7 8}$ & 1053 & 500 & 578 & 1053 & $\begin{array}{c}390 \\
(-110)\end{array}$ \\
\hline Dry & $\mathbf{5 7 8}$ & 894 & 500 & 578 & $\begin{array}{c}781 \\
(-113)\end{array}$ & 0 \\
\hline
\end{tabular}

A plan for reservoir operating rules for wet, normal, and dry years, as well as the actual operating rule of the Keuliling Reservoir, was prepared after updating the reservoir operating rules (Figure 1). The actual operating rule is based on the daily recorded reservoir gate opening intakes.

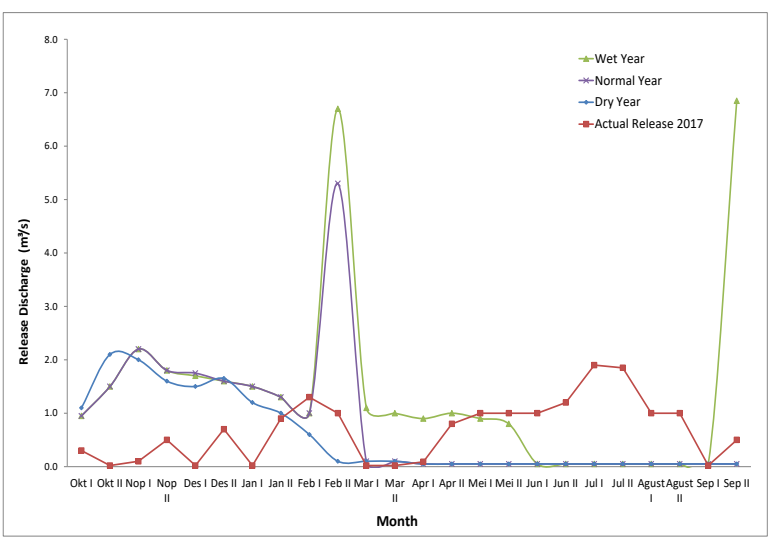

Fig. 1. The operating rule plan for Keuliling reservoir on wet, normal, and dry years

There are significant differences between the actual and planned operating rules. The differences happened due to: A decline in the reservoir capacity caused by sedimentation, and on actual release, a large amount of water supply was observed in the third planting season (June - September). However, the third planting season was not included in the normal reservoir operating rule.

\section{Conclusion}

This study succeeded in providing an update on the operating pattern of the Keuliling Reservoir due to changes in the reservoir capacity. A decline in the reservoir capacity is caused by sedimentation and actual release. Optimization will result in reservoir operations that can supply water according to the target rice field area in normal and wet years. The irrigation area is 578 hectares (ha) for Group I (Keuliling Upstream Irrigation Area) and 1053 ha for Group II (Keuliling Downstream Irrigation Area). The operation of reservoirs in dry years with water deficit has affected the water supply for irrigation. However, in the dry year of Group I (DI Keuliling Hulu), with an irrigation area of 578 ha, the rice planting pattern (one rice planting season) begins with the planting season in October I. In addition, in Group II (DI Keuliling Hilir), with an irrigation area of 781 ha, the rice planting pattern (one rice planting season) starts the planting season in October II. The reduced inflows during dry years have decreased the target irrigation area by 113 ha.

\section{References}

1. T. Bohmelt, T. Bernauer, H. Buhaug, N. P. Gleditsch, T. Tribaldos, and G. Wischnath, Global Environmental Change 29 (2014) 337348.

2. H. Wang, E. D.Brill, R. S.Ranjithan, A. Sankarasubramanian, Advances in Water Resources 78 (2015) 9-21.

3. C. S. Lee, Chemosphere 87 (2012) 608-613.

4. A. Azmeri, I.K.Hadihardaja, N. Shaskia, K.S.Admaja, Proceedings of the 3rd International Conference on Construction and Building Engineering (ICONBUILD) (2017) AIP Conf. Proc. 1903, 100001-1-100001-9.

5. D. A. Wulandari, Master thesis. Diponegoro University. Semarang (2013).

6. N.M. Khan, M.S. Babel, R. Clemente, T. Tingsanchali, Water Resources Management 26 (2012) 11

7. D. A. Wulandari, D. Legono, S. Darsono, International Journal of Science and Engineering. Vol. 6(1)4 (2014)16-23

8. V. Tinoco, P. Willems, G. Wyseure, and F. Cisneros, Journal of Hydrology: Regional Studies 5 (2016) 213-225

9. A. Armido, A. Azmeri, E. Fatimah, N. Nurbaiti, S.N. Yolanda. 2020. The sedimentation datasets of Keuliling reservoir. Data in Brief. 32106181. 